\title{
SUBSTITUSI TEPUNG KEDELAI DENGAN TEPUNG BIJI KORO PEDANG (Canavalia ensiformis) TERHADAP PERTUMBUHAN, SURVIVAL RATE DAN EFISIENSI PAKAN IKAN NILA MERAH
}

\author{
SUBSTITUTION OF SOYBEAN MEAL WITH SWORD BEAN SEED MEAL (Canavalia \\ ensiformis) ON GROWTH, SURVIVAL RATE AND FEED EFFICIENCY OF RED TILAPIA
}

\author{
Ega Centyana, Yudi Cahyoko dan Agustono
}

Fakultas Perikanan dan Kelautan Universitas Airlangga

Kampus C Mulyorejo - Surabaya, 60115 Telp. 031-5911451

\begin{abstract}
Red tilapia is kind of freshwater culture fish is quite popular because it has several advantages compared with other types of freshwater fish. To fullfil the demand of red tilapia can be overcome by cultivation. Effort to increase the production of red tilapia is to improve the quality of feed. The purpose of this study was to try the effect of the use of sword bean seed meal on the growth rate, survival rate and feed efficiency of red tilapia.

The research method is experimental with completely randomized design (CRD) with five treatments and four replications. The treatments used were: (A) sword beans seed meal at $0 \%$ and soybean meal by $50 \%$, (B) $10 \%$ sword beans seed meal and $40 \%$ soybean meal, (C) $20 \%$ sword beans seed meal and 30\% soybean meal, (D) 30\% sword beans seed meal and 20\% soybean meal and (E) $40 \%$ sword beans seed meal and $10 \%$ soybean meal. The main parameters that measured were growth, survival rate and feed efficiency. Secondary parameters measured were water quality. Analysis of the data using analysis of variance (ANOVA) and to know the difference between treatments using Duncan's Multiple Range Test.

Results showed the administration of sword bean seed meal on feed rations provide a significantly different effect $(\mathrm{p}<0.05)$ on the growth and feed efficiency but not significantly on survival rate of red tilapia $(p>0.05)$. Highest daily growth rate obtained on treatment $B$ on feed containing $10 \%$ of sword bean meal $(1.20 \%)$ was significantly different than treatment A $(1.02 \%), \mathrm{C}(0.88 \%), \mathrm{D}(0.85 \%)$ and $\mathrm{E}(0.75 \%)$. Lowest daily growth rate was treatment $\mathrm{E}$ that significantly different with treatment $\mathrm{A}$ and $\mathrm{B}$ but not significantly different with treatments $\mathrm{C}$ and $\mathrm{D}$. Highest feed efficiency obtained on treatment B (30.29 \%) was not significantly different than treatment A $(27.56 \%), \mathrm{C}(25.95 \%)$ and D $(27.78 \%)$. Lowest feed efficiency was treatment E (17.84 \%) significantly different than treatment B. Subtitution of sword bean seed meal in feed rations gave result that was not significantly different effect on the level of survival of red tilapia. Water quality of red tilapia rearing media was temperature range between $25-28^{\circ} \mathrm{C}, \mathrm{pH} 7-8$, dissolved oxygen $2-5 \mathrm{mg} / \mathrm{L}$ and ammonia 1.5 to $3.0 \mathrm{mg} / \mathrm{L}$.
\end{abstract}

Keywords : Red tilapia, Canavalia ensiformis, growth, survival rate, feed efficiency

\section{Pendahuluan}

Ikan nila merah merupakan salah satu jenis ikan budidaya air tawar yang mempunyai prospek cukup baik untuk dikembangkan karena banyak digemari oleh masyarakat. Hal ini disebabkan ikan nila merah memiliki beberapa keunggulan dibandingkan dengan jenis ikan air tawar lainnya, yaitu mudah dibudidayakan, memiliki daging yang tebal dan kandungan duri yang sedikit sehingga dapat diolah menjadi berbagai produk olahan (Rostini, 2007 dalam Hapsari, 2010).

Pemenuhan permintaan ikan nila yang relatif tinggi tersebut dapat diatasi dengan cara budidaya nila merah secara intensif. Salah satu kegiatan budidaya yang menunjang kegiatan budidaya secara intensif adalah pemberian pakan. Menurut Handajani (2008) usaha budidaya ikan sangat dipengaruhi oleh ketersediaan pakan yang cukup dalam jumlah dan kualitasnya untuk mendukung kualitas yang maksimal. Biaya pakan dalam budidaya ikan nila merah bisa mencapai $60 \%-70 \%$ biaya produksi, maka diperlukan pengelolaan pakan yang efektif dan efisien.

Salah satu sumber bahan yang sering digunakan dalam proses formulasi pakan ikan adalah tepung kedelai. Bahan pakan kedelai merupakan bahan pakan yang relatif mahal dan merupakan bahan pakan yang masih diimpor. Ketergantungan terhadap tepung kedelai dalam pemakaian formulasi pakan, maka perlu dicari 
alternatif sumber bahan baku lokal yang mudah diperoleh, ketersediaan melimpah, berkesinambungan, dan mempunyai nilai gizi yang cukup tinggi. Salah satu bahan alternatif pengganti tepung kedelai adalah biji koro pedang (Canavalia ensiformis). Biji koro pedang mengandung protein $23-27,6 \%$ lemak 2,3-3,9\% karbohidrat 45,2-56,9\% serat kasar 4,9-8,0\% dan mineral 2,27-4,2\% (Kay dkk., (1979) dalam Pramita, 2008). Tingginya kandungan nutrisi pada biji koro pedang tersebut dapat dimanfaatkan sebagai bahan alternatif pengganti tepung kedelai.

Tujuan dari penelitian ini adalah mengetahui pengaruh penggunaan tepung biji koro pedang sebagai substitusi tepung kedelai dalam pakan buatan terhadap pertumbuhan, survival rate dan efisiensi pakan ikan nila merah. Penelitian ini diharapkan dapat memberikan informasi mengenai penggunaan tepung biji koro pedang pada pakan buatan terhadap pengaruh pertumbuhan, survival rate dan efisiensi pakan ikan nila merah.

\section{Materi dan Metode}

Penelitian dilaksanakan pada bulan Juni sampai Juli 2012 di Fakultas Perikanan Dan Kelautan Universitas Airlangga.

Alat yang digunakan dalam pemeliharaan ikan nila merah adalah 20

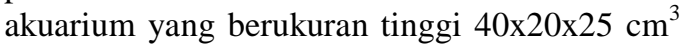
dengan kapasitas volume 20 liter, aerator, selang penyipon, seser, timbangan digital, penggaris besi, ayakan tepung, gilingan, penumbuk, $\mathrm{pH}$ paper, termometer, DO meter dan test kit.

Ikan Uji

Ikan uji yang digunakan dalam penelitian adalah ikan nila merah dengan umur 1 bulan, ukuran panjang tubuh berkisar antara 3-5 $\mathrm{cm}$ dan berat tubuh rata - rata 1,3 gram. Jumlah ikan nila yang dibutuhkan 100 ekor yang dibagi dalam 20 akuarium.

Media Pemeliharaan

Media pemeliharaan yang digunakan dalam penelitian ini adalah air tawar dengan volume 10 liter per akuarium.

Pakan

Bahan baku pakan yang akan digunakan dalam penelitian ini adalah tepung koro pedang, tepung ikan, tepung kedelai, tepung jagung, dedak padi, tepung tapioka, tetes tebu, mineral dan vitamin mix.
Penelitian ini menggunakan Rancangan Acak Lengkap (RAL) dimana semua dikondisikan sama kecuali perlakuan (Kusriningrum, 2008). Perlakuan yang digunakan adalah 5 perlakuan dengan 4 kali ulangan. Perlakuan yang diberikan adalah perbedaan dosis tepung biji koro pedang dalam ransum pakan.

\section{Persiapan Ikan Uji}

Ikan nila merah didapatkan dari Balai Pengembangan Budidaya Air Tawar (BPBAT) Umbulan. Ikan yang digunakan dalam penelitian ini adalah ikan nila merah yang berumur 1 bulan dengan bobot rata-rata 1,3 gram dengan panjang berkisar $3-5 \mathrm{~cm}$. Ikan nila yang digunakan dalam penelitian ini adalah ikan yang sehat, tidak terserang penyakit dan homogen beratnya.

Pembuatan Pakan

Bahan baku pakan yang akan digunakan untuk pakan dianalisis proksimat terlebih dahulu untuk mengetahui kandungan nutrisinya. Bahan baku pakan yang sudah dianalisis proksimat, kemudian dibuat pakan sesuai perlakuan dengan kandungan protein sebesar 30\%. Perlakuan tersebut adalah : A (0\%), B (10\%), C (20\%), D (30\%), E (40\%). Hal ini sesuai dengan pernyataan Suyanto (2009) bahwa pakan buatan dengan kandungan protein sebesar 30-35\% memberikan pertumbuhan yang terbaik pada ikan nila merah. Formulasi pakan dihitung menggunakan metode uji coba. Setelah diformulasi, bahan baku pakan dijadikan pelet selanjutnya pakan uji yang sudah jadi pelet dianalisis proksimat. Komposisi pakan dapat dilihat pada tabel 1 dan hasil analisis proksimat terdapat pada tabel 2 .

Persiapan Akuarium dan Air Media Pemeliharaan

Persiapan penelitian meliputi meliputi persiapan akuarium dan air media pemeliharaan. Akuarium yang akan digunakan dalam penelitian ini disterilisasi terlebih dahulu dengan menggunakan klorin 400 ppm kemudian dibilas dengan menggunakan air bersih kemudian dikeringkan (BBL, 2003). Media pemeliharaan yang digunakan dalam penelitian ini adalah air tawar. Air tawar tersebut dimasukkan ke dalam 20 akuarium. Tiap akuarium diisi dengan air 10 liter.

Pelaksanaan Penelitian 
Tabel 1. Komposisi Pakan

\begin{tabular}{|c|c|c|c|c|c|c|}
\hline \multirow[t]{2}{*}{ No. } & \multirow[t]{2}{*}{ Bahan Pakan } & \multicolumn{5}{|c|}{ Perlakuan } \\
\hline & & A & B & $\mathrm{C}$ & $\mathrm{D}$ & $\mathrm{E}$ \\
\hline 1. & Tepung Ikan & 17,59 & 20,19 & 22,79 & 25,39 & 28 \\
\hline 2. & Tepung Koro Pedang & - & 10 & 20 & 30 & 40 \\
\hline 3. & Tepung Kedelai & 50 & 40 & 30 & 20 & 10 \\
\hline 4. & Tepung Jagung & 12,41 & 9,81 & 7,21 & 4,61 & 2 \\
\hline 5. & Dedak Padi & 13 & 13 & 13 & 13 & 13 \\
\hline 6. & Tepung Tapioka & 3 & 3 & 3 & 3 & 3 \\
\hline 7. & Tetes Tebu & 2 & 2 & 2 & 2 & 2 \\
\hline 8. & Vitamin Mix & 2 & 2 & 2 & 2 & 2 \\
\hline \multicolumn{2}{|c|}{ Jumlah bahan (g) } & 100 & 100 & 100 & 100 & 100 \\
\hline
\end{tabular}

Tabel 2. Hasil analisis proksimat dalam $100 \%$ bahan kering

\begin{tabular}{|c|c|c|c|c|c|c|}
\hline Perlakuan & Protein (\%) & $\begin{array}{c}\text { Lemak } \\
(\%)\end{array}$ & $\begin{array}{c}\text { Serat kasar } \\
(\%)\end{array}$ & Abu (\%) & BETN (\%) & $\begin{array}{c}\text { DE } \\
(\mathrm{Kkal} / \mathrm{kg})\end{array}$ \\
\hline A & 29,55 & 11,88 & 5,77 & 7,95 & 44,84 & 3175,2 \\
B & 32,24 & 7,92 & 4,81 & 8,46 & 46,56 & 3054,1 \\
C & 30,84 & 8,41 & 5,36 & 8,22 & 47,16 & 3073,6 \\
D & 31,39 & 8,40 & 5,34 & 8,38 & 46,49 & 3074,7 \\
E & 31,04 & 8,40 & 5,34 & 8,18 & 47,04 & 3076,3 \\
\hline
\end{tabular}

Keterangan : Hasil Analisis Proksimat Unit Layanan Pemeriksaan, Konsultasi dan Pelatihan, Fakultas Kedokteran Hewan, Universitas Airlangga

BETN : Bahan Ekstrak Tanpa Nitrogen

DE : Energi dapat dicerna $1 \mathrm{~g}$ protein $=3,5 \mathrm{kkal} \mathrm{DE} 1 \mathrm{~g}$ lemak $=8,1 \mathrm{kkal} \mathrm{DE}, 1 \mathrm{~g}$ karbohidrat $=2,5 \mathrm{kkal}$ DE $(\mathrm{NRC}, 1997)$

Bahan penyusun pakan dianalisis proksimat terlebih dahulu untuk mengetahui kandungan nutrisinya. Kemudian pakan disusun sesuai dengan dosis yang telah ditentukan yaitu pemberian tepung koro pedang $0 \%, 10 \%, 20 \%$, $30 \%, 40 \%$. Setelah disusun sesuai dengan dosis yang telah ditentukan, pakan uji dibuat dalam bentuk pelet dan ukurannya disesuaikan dengan bukaan mulut ikan uji. Pelet yang telah jadi kemudian dianalisis proksimat lagi.

Ikan nila merah ditempatkan di akuarium. Ada 5 perlakuan, setiap perlakuan menggunakan 4 akuarium. Masing-masing akuarium diisi ikan dengan padat tebar 1 ekor/ 2 liter. Sebelumnya ikan diadaptasikan terlebih dahulu selama 7 hari dengan tujuan adaptasi lingkungan yang baru dan beradaptasi dengan pakan uji supaya ikan mau makan sewaktu dilaksanakan penelitian. Setelah masa adaptasi selesai, ikan dipuasakan selama 24 jam dengan tujuan untuk menghilangkan pengaruh sisa pakan dalam tubuh ikan.

Media pemeliharaan berupa air tawar. Air tersebut ditempatkan di dalam akuarium berukuran 40x20x25 $\mathrm{cm}^{3}$ sebanyak 10 liter/akuarium. Kualitas air pada media pemeliharaan dijaga agar kondisinya tetap baik dengan melakukan penyifonan kotoran sisa pakan dan metabolisme dalam akuarium setiap hari. Penyifonan ini sekaligus mengganti air sebanyak 50\% dari air sebelumnya. Air baru yang ditambahkan berasal dari bak tandon. Air tandon berasal dari PDAM yang diendapkan selama 24 jam. Pengukuran dan pencatatan kualitas air dilakukan setiap hari pada pagi, siang dan sore hari diantaranya $\mathrm{pH}$ dan suhu. Kelarutan oksigen dan amoniak diukur dan dicatat setiap 7 hari sekali.

Pakan uji yang digunakan berbentuk pelet yang telah disesuaikan dengan ukuran bukaan mulut ikan. Sebelum pakan tersebut diberikan, dilakukan penimbangan berat ikan uji untuk menentukan jumlah pakan yang akan diberikan. Pakan diberikan tiga kali sehari sebanyak 5\% dari keseluruhan berat tubuh ikan uji. Pemberian pakan dilakukan pada pukul 07.00, 12.00 dan 16.00 WIB. Pengukuran pertumbuhan dilakukan setiap 7 hari sekali. 
Berat rata-rata ikan pada waktu awal dan berat rata-rata ikan pada saat pengukuran dicatat dan dihitung untuk mengetahui laju pertumbuhan ikan. Setelah dihitung, dilakukan penyesuaian jumlah pakan yang diberikan. Penelitian ini dilaksanakan selama 35 hari. Pada akhir penelitian, jumlah pakan yang dikonsumsi, bobot biomass ikan pada akhir penelitian dan bobot total ikan yang mati selama penelitian dicatat dan dihitung untuk mengetahui efisiensi pakan yang diberikan. Jumlah ikan pada saat akhir pemeliharaan dan awal pemeliharaan dicatat dan dihitung untuk mengetahui survival rate ikan selama penelitian.

Parameter utama yang diamati dalam penelitian ini adalah pertumbuhan, survival rate dan efisiensi pakan ikan nila merah. Sedangkan parameter penunjangnya adalah pengukuran kualitas yang meliputi suhu, $\mathrm{pH}$, oksigen terlarut dan amoniak.

\section{Analisis Data}

Data yang diperoleh, diolah dengan menggunakan Analysis of Variant (ANOVA) untuk mengetahui pengaruh perlakuan. Apabila dari analisis ragam diketahui bahwa perlakuan menunjukkan pengaruh yang berbeda nyata, maka untuk membandingkan pengaruh perlakuan dilanjutkan Uji Jarak Berganda Duncan (Kusriningrum, 2008).

\section{Hasil dan Pembahasan}

Grafik hubungan antara pemeliharaan dengan berat rata-rata ikan nila merah dapat dilihat pada Gambar 1.

Grafik diatas menunjukkan pertumbuhan berat rata-rata ikan nila merah dengan perlakuan pengaruh penggunaan tepung biji koro pedang pada pakan buatan yang berbeda. Grafik laju pertumbuhan diatas menunjukkan rata-rata pertumbuhan berat semakin meningkat dengan bertambahnya waktu pemeliharaan. Data rata-rata pertumbuhan harian dapat dilihat pada tabel 3.

Berdasarkan hasil uji Jarak Berganda Duncan (Duncan's Multiple Range Test), maka diketahui bahwa laju pertumbuhan harian tertinggi adalah perlakuan B $(1,20 \%)$ pada

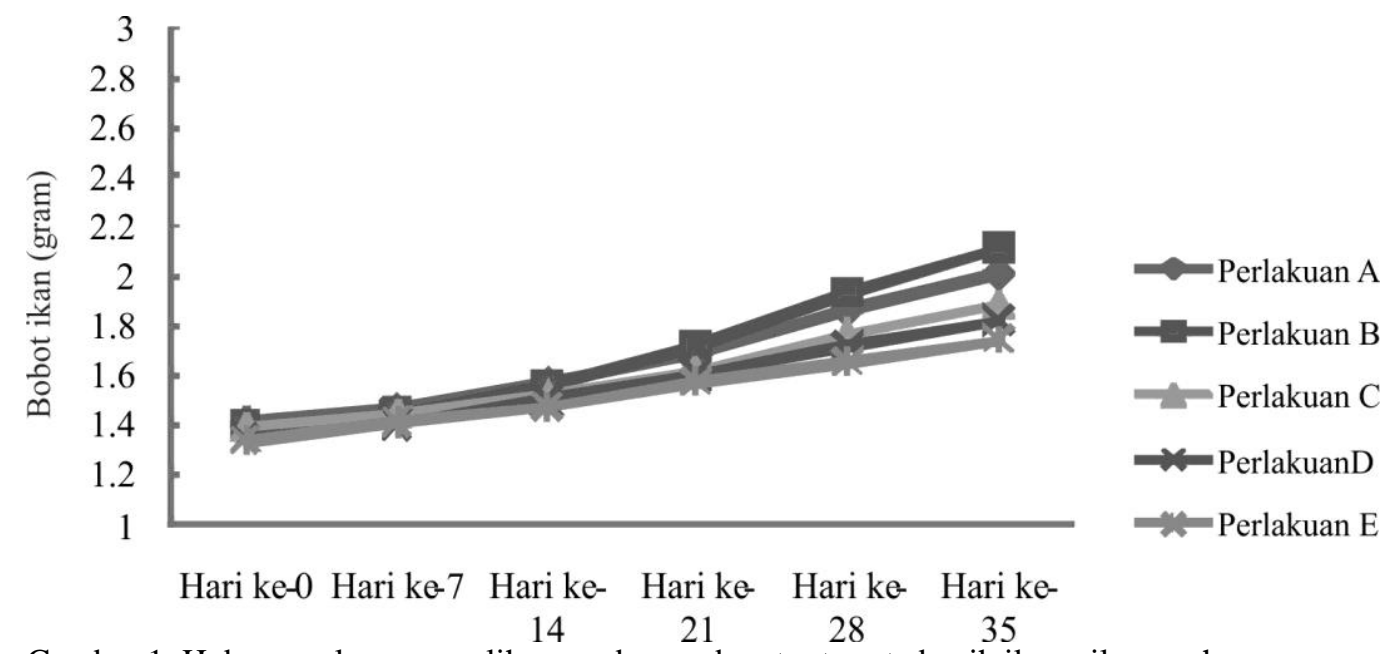

Gambar 1. Hubungan lama pemeliharaan dengan berat rata-rata benih ikan nila merah

Tabel 3. Data rata-rata laju pertumbuhan harian (\%) ikan nila merah pada setiap perlakuan selama 35 hari

\begin{tabular}{|c|c|c|}
\hline Perlakuan & LPH $(\%) \pm$ SD & Transformasi $\sqrt{\mathrm{y}} \pm$ SD \\
\hline Pakan A & $1,02 \pm 0,1578$ & $1,01^{\mathrm{b}} \pm 0,0761$ \\
Pakan B & $1,20 \pm 0,1315$ & $1,09^{\mathrm{a}} \pm 1,9061$ \\
Pakan C & $0,88 \pm 0,0574$ & $0,93^{\mathrm{bc}} \pm 0,0316$ \\
Pakan D & $0,85 \pm 0,2458$ & $0,91^{\mathrm{bc}} \pm 0,1334$ \\
Pakan E & $0,75 \pm 0,1929$ & $0,86^{\mathrm{c}} \pm 0,1353$ \\
\hline
\end{tabular}

Keterangan :

LPH : Laju Pertumbuhan Harian

SD : Standar Deviasi

a, b : Superskrip yang berbeda pada kolom yang sama menunjukkan perbedaan nyata $(\mathrm{p}<0,05)$ Superskrip yang sama pada kolom yang sama menunjukkan tidak terdapat perbedaan nyata ( $>>0,05)$ 
Tabel 4. Data rata-rata tingkat kelulushidupan ikan nila merah selama 35 hari pemeliharaan

\begin{tabular}{|c|c|c|}
\hline Perlakuan & SR $(\%) \pm$ SD & Transformasi $\sqrt{\mathrm{y} \pm \mathrm{SD}}$ \\
\hline Pakan A & $65 \pm 10$ & $53,93 \pm 6,33$ \\
Pakan B & $55 \pm 10$ & $47,88 \pm 5,77$ \\
Pakan C & $55 \pm 19,1485$ & $48,16 \pm 11,54$ \\
Pakan D & $55 \pm 19,1485$ & $48,16 \pm 11,54$ \\
Pakan E & $50 \pm 11,5470$ & $45 \pm 6,6626$ \\
\hline
\end{tabular}

Keterangan :

SR : Tingkat Kelulushidupan ikan nila merah

SD : Tingkat Kelulushidupan

a, b : Superskrip yang berbeda pada kolom yang sama menunjukkan tidak berbeda nyata $(p>0,05)$

Tabel 5. Data rata-rata efisiensi pakan ikan nila merah selama 35 hari pemeliharaan

\begin{tabular}{|c|c|c|}
\hline Perlakuan & Efisiensi pakan $(\%) \pm$ SD & Transformasi $\sqrt{\mathrm{y}} \pm$ SD \\
\hline Pakan A & $27,56 \pm 10$ & $53,93^{\mathrm{ab}} \pm 6,33$ \\
Pakan B & $30,29 \pm 10$ & $47,88^{\mathrm{a}} \pm 5,77$ \\
Pakan C & $25,95 \pm 19,1485$ & $48,16^{\mathrm{ab}} \pm 11,54$ \\
Pakan D & $27,78 \pm 19,1485$ & $48,16^{\mathrm{ab}} \pm 11,54$ \\
Pakan E & $17,84 \pm 11,5470$ & $45^{\mathrm{b}} \pm 6,66$ \\
\hline
\end{tabular}

Keterangan :

SR : Tingkat Kelulushidupan ikan nila merah

SD : Tingkat Kelulushidupan

a, $b \quad$ : Superskrip yang berbeda pada kolom yang sama menunjukkan berbeda nyata $(\mathrm{p}<0,05)$

pakan yang mengandung tepung biji koro pedang sebesar $10 \%$ yang berbeda nyata $(\mathrm{p}<0,05)$ dengan perlakuan A, C, D, E. Laju pertumbuhan harian terendah adalah perlakuan E yang berbeda nyata dengan perlakuan A dan $\mathrm{B}$, tapi tidak berbeda nyata $(\mathrm{p}>0,05)$ dengan perlakuan $\mathrm{C}$ dan D.

Data rata-rata tingkat kelulushidupan ikan nila merah yang diberi pakan buatan dengan penggunaan tepung biji koro pedang dengan berbagai dosis terdapat pada tabel 4 .

Hasil uji statistik menunjukkan bahwa penggunaan tepung biji koro pedang pada pakan buatan sebesar $0 \%, 10 \%, 20 \%, 30 \%$ dan $40 \%$ menghasilkan rasio SR (Survival Rate) yang tidak berbeda nyata $(\mathrm{p}>0,05)$.

Data rata-rata efisiensi pakan ikan nila merah selama 35 hari pemeliharaan terdapat pada tabel 5 .

Hasil uji statistik menunjukkan bahwa penggunaan tepung biji koro pedang pada pakan buatan sebesar $0 \%, 10 \%, 20 \%, 30 \%$ dan $40 \%$ menghasilkan efisiensi pakan yang berbeda nyata $(\mathrm{p}<0,05)$. Berdasarkan hasil uji Jarak Berganda Duncan (Duncan's Multiple Range Test), maka diketahui bahwa efisiensi pakan tertinggi adalah perlakuan B $(30,29 \%)$ pada pakan yang mengandung tepung biji koro pedang sebesar $10 \%$ yang tidak berbeda nyata ( $p>0,05)$ dengan A, C dan D. Efisiensi pakan terendah adalah perlakuan $\mathrm{E}$ yang berbeda nyata $(\mathrm{p}<0,05)$ dengan $\mathrm{B}$
Pertumbuhan adalah pertambahan ukuran panjang atau berat dalam suatu waktu (Effendie, 1997). Salah satu yang mempengaruhi pertumbuhan adalah pakan. Pemberian pakan yang berkualitas baik dapat menunjang pertumbuhan ikan (Fujaya, 2004). Pemberian pakan yang berkualitas dapat menunjang pertumbuhan ikan. Pakan yang berkualitas dapat dilihat berdasarkan kandungan nutrisinya yaitu protein, lemak, karbohidrat, mineral dan vitamin (Mudjiman, 2002).

Hasil analisis statistik menunjukkan bahwa laju pertumbuhan berbeda nyata antar perlakuan $(\mathrm{p}<0,05)$. Laju pertumbuhan tertinggi terdapat pada perlakuan B yang berbeda nyata $(p<0,05)$ dengan perlakuan A, C, D, E. Laju pertumbuhan harian terendah adalah perlakuan E yang tidak berbeda nyata $(p>0,05)$ dengan perlakuan A, C, D. Hal ini menunjukkan bahwa penggunaan tepung biji koro pedang dalam ransum pakan dapat menunjukkan laju pertumbuhan yang lebih baik dibandingkan dengan penggunaan tepung kedelai.

Laju pertumbuhan pada perlakuan B menunjukkan perbedaan yang nyata $(p<0,05)$. Hal ini disebabkan karena pada perlakuan B mempunyai nilai efisiensi pakan sebesar $33,36 \%$ yang merupakan nilai tertinggi dibandingkan dengan perlakuan yang lain. Hal ini dikarenakan pakan yang diberikan dapat diserap dengan baik sehingga dapat dimanfaatkan untuk pertumbuhan ikan. Pada perlakuan $B$ juga mempunyai kandungan 
protein sebesar $32,24 \%$ yang merupakan nilai protein tertinggi dibandingkan dengan perlakuan yang lainnya. Menurut Watanabe dan Cho (1988), protein mempunyai peran penting untuk fungsi jaringan normal, pertahanan dan pertumbuhan. Protein dalam fungsinya tidak hanya sebagai penyusun utama tubuh ikan tetapi juga berperan penting sebagai enzim dan hormon - hormon yang menunjang metabolisme. Perlakuan B juga mempunyai nilai serat kasar yang kecil yaitu $4,81 \%$. Serat kasar mempengaruhi nilai energi karena terdapat korelasi antara kadar serat kasar dengan energi yang tersedia dalam pakan. Semakin tinggi serat kasar pakan maka semakin rendah jumlah energi yang tersedia. Hal ini disebabkan serat kasar tidak mampu menyediakan energi yang dapat dimanfaatkan oleh ikan. Serat kasar yang berisi selulosa, hemiselulosa dan lignin relatif sulit dicerna dan merupakan sumber energi yang rendah (Anggorodi, 1990).

Perlakuan E menunjukkan perbedaan yang tidak nyata $(p>0,05)$ bila dibandingkan dengan perlakuan lainnya. Hal ini disebabkan karena nilai efisiensi pakan pada perlakuan $\mathrm{E}$ nilainya rendah yaitu $24,60 \%$. Efisiensi pakan akan berkorelasi positif terhadap pertumbuhan, jika ikan mampu mengefisiensikan pakan yang diberikan secara maksimum maka pertumbuhan akan semakin cepat terjadi. Faktor penting yang mempengaruhi tinggi rendahnya efisiensi pakan adalah sumber nutrisi dan jumlah dari tiap komponen sumber nutrisi dalam pakan tersebut. Jumlah dan kualitas pakan yang diberikan kepada ikan berpengaruh terhadap pertumbuhan ikan. Semakin tinggi nilai efisiensi pakan maka respon ikan terhadap pakan tersebut semakin baik yang ditunjukkan dengan pertumbuhan ikan yang cepat (Susilo dkk, 2005). Selain dari faktor efisiensi pakan, juga dipengaruhi oleh kelengkapan dan keseimbangan jumlah asam amino yang terdapat pada pakan yang diberikan. Pada koro pedang tidak mengandung asam amino arginin dan triptofan. Menurut Paramitha (2009), arginin merupakan asam amino yang sangat diperlukan bagi pertumbuhan optimal ikan muda, arginin juga berperan dalam biosintesis urea. Sedangkan triptofan merupakan asam amino pembatas dalam bahan makanan sumber protein nabati.

Kelangsungan hidup adalah peluang hidup suatu individu dalam waktu tertentu (Effendie, 2002). Pemberian pakan dengan kandungan nutrien yang cukup dan seimbang akan berpengaruh terhadap kesehatan dan kelangsungan hidup ikan (Irianto, 2005). Kualitas pakan dapat dilihat dari komposisi zat gizinya seperti kandungan protein, lemak dan karbohidrat serta perlu diperhatikan kandungan energinya (Djajasewaka, 1985).

Hasil uji statistik menunjukkan bahwa tidak terdapat perbedaan nyata antar perlakuan ( $>0,05)$. Berdasarkan analisis statistik tersebut diketahui bahwa pemberian tepung biji koro pedang tidak dapat menunjukkan kelangsungan hidup yang lebih baik daripada dengan menggunakan tepung kedelai saja, hal ini menunjukkan bahwa kualitas pakan dengan menggunakan tepung biji koro pedang dalam ransum pakan ikan nila merah tidak lebih baik jika dibandingkan dengan kualitas pakan yang hanya menggunakan tepung kedelai saja dalam peningkatan kelangsungan hidup ikan nila merah.

Efisiensi pakan merupakan persentase perbandingan berat ikan dengan jumlah pakan terhadap pertumbuhan (Lovell, 1988). Pakan yang sesuai dengan kebutuhan nutrisi ikan terutama protein serta sesuai dengan sifat dan kebiasaan makan ikan dapat meningkatkan efisiensi pakan (Nofyan, 2005). Semakin tinggi nilai efisiensi pakan berarti kualitas pakan yang diberikan juga semakin baik (Halver, 1972 dalam Hariyadi dkk., 2005). Nilai efisiensi pakan yang semakin mendekati nilai $100 \%$ menunjukkan bahwa pakan tersebut memiliki kualitas yang semakin baik (Gusrina, 2008).

Hasil uji statistik menunjukkan bahwa nilai efisiensi pakan berbeda nyata antar perlakuan $(\mathrm{p}<0,05)$. Efisiensi pakan tertinggi terdapat pada perlakuan B $(33,36 \%)$ dengan penggunaan tepung biji koro pedang sebesar $10 \%$ yang berbeda nyata dengan perlakuan $\mathrm{E}$ $(24,60 \%)$ dengan penggunaan tepung biji koro pedang $40 \%$. Hal ini disebabkan perlakuan B memiliki laju pertumbuhan yang lebih tinggi dibandingkan dengan perlakuan lain, sehingga pemanfaatan pakan dalam perlakuan B lebih efisien atau lebih termanfaatkan dibandingkan dengan perlakuan lainnya. Nilai energi pakan pada masing - masing perlakuan hampir sama, sehingga dapat dikatakan bahwa pemberian tepung biji koro pedang yang disubstitusikan dengan tepung kedelai antar perlakuan menjadi faktor pembeda dalam laju pertumbuhan dan efisiensi pakan ikan nila merah.

Parameter penunjang dari penelitian ini adalah parameter kualitas air seperti suhu, DO, pH dan amonia. Air sebagai media hidup ikan yang dipelihara harus memenuhi persyaratan (Arie, 1999). Kualitas air perlu dilakukan pengontrolan agar kualitas air tetap berada dalam kondisi yang optimal, sehingga menciptakan lingkungan yang sesuai dengan habitat ikan nila merah. Kualitas air dijaga tetap optimum dengan dilakukan penyiponan setiap 
hari sekali dan pergantian air sebanyak $50 \%$ dari total volume setiap tujuh hari sekali.

Suhu adalah faktor lingkungan yang berpengaruh terhadap kecepatan metabolisme tubuh ikan. Kecepatan metabolisme ikan akan berlangsung optimal pada suhu optimal (Philips, 1972). Menurut Kinne dalam Sikong (1982) suhu tinggi dapat menyebabkan kekeringan sel akibat penguapan, kekentalan protoplasma meningkat, membran sel lebih permeable. Perubahan suhu lingkungan menyebabkan perubahan energi untuk pertumbuhan, laju respirasi dan laju konsumsi oksigen. Selama penelitian ini berlangsung suhu tercatat antara 25-28 ${ }^{\circ} \mathrm{C}$. Hal ini sesuai dengan Khairuman dan Amri (2003) yang menyatakan suhu air optimal untuk ikan nila merah yaitu $25-30{ }^{\circ} \mathrm{C}$.

Nilai $\mathrm{pH}$ suatu perairan dapat mempengaruhi pertumbuhan bagi biota didalamnya, bahkan dapat menyebabkan kematian. Effendi (2003) menyatakan bahwa sebagian besar biota akuatik menyukai $\mathrm{pH}$ sekitar 7-8,5 dan pada nilai $\mathrm{pH}$ kurang dari 4 maka sebagian besar biota akuatik mati karena tidak dapat bertoleransi terhadap $\mathrm{pH}$ rendah. Selama penelitian berlangsung $\mathrm{pH}$ tercatat antara 7-8. Hal ini sesuai dengan pernyataan Khairuman dan Amri (2003) bahwa kisaran pH yang diperlukan oleh ikan nila yaitu 6-9.

Kandungan oksigen terlarut selama pemeliharaan berada dalam batas toleransi. Oksigen terlarut selama penelitian adalah 2-5 mg/L. Menurut Khairuman dan Amri (2003) oksigen terlarut yang dibutuhkan ikan yaitu minimal $3 \mathrm{mg} / \mathrm{L}$. Dengan demikian oksigen terlarut pada pemeliharaan ikan nila merah masih memenuhi persyaratan.

Sumber amoniak di perairan dapat berasal dari sisa pakan maupun kotoran ikan (Mulyana, 2004). Menurut BSNI (2009) batas toleransi amoniak di perairan untuk ikan nila merah adalah tidak melebihi 0,5 $\mathrm{mg} / \mathrm{L}$. Sedangkan kadar amoniak di perairan saat penelitian adalah 1,5-3,0 $\mathrm{mg} / \mathrm{L}$. Dengan demikian kadar amoniak di perairan pemeliharaan ikan nila merah tidak memenuhi persyaratan.

\section{Kesimpulan}

Penggunaan tepung biji koro pedang sebagai substitusi tepung kedelai pada pakan buatan memberikan pengaruh yang nyata terhadap partumbuhan dan efisiensi pakan pada ikan nila merah, tetapi tidak berpengaruh terhadap survival rate ikan nila merah. Laju pertumbuhan harian tertinggi $(1,20 \%)$ dan efisiensi pakan tertinggi $(30,29 \%)$ diperoleh pada perlakuan $\mathrm{B}$ dengan pakan yang mengandung tepung biji koro pedang sebesar $10 \%$. Pemberian tepung biji koro pedang pada ransum pakan tidak memberikan pengaruh yang berbeda nyata terhadap tingkat kelulushidupan ikan nila merah.

Subsitusi tepung biji koro pedang pada tepung kedelai dapat dilanjutkan penelitian dengan menggunakan komposisi yang sama tetapi tanpa metode penghitungan ransum isoprotein.

\section{Daftar Pustaka}

Anggorodi, R. 1990. Ilmu Makanan Ternak. Gramedia, Jakarta.

Arie, U. 1999. Pembenihan dan Pembesaran Ikan Nila Gift. Penebar Swadaya. Jakarta. 128 hal.

Badan Standardisasi Nasional Indonesia (BSNI). 2009. Produksi Benih Ikan Nila Hitam (Oreochromis niloticus) Kelas Benih Sebar. SNI : 6141:2009. Jakarta. 16 hal

Balai Budidaya Laut (BBL). Direktorat Jenderal Perikanan Budidaya Departemen Kelautan Dan Perikanan. 2003. Penanganan Penyakit Ikan Budidaya Laut. ISBN : 979-98017-1-0. No : 12. Lampung. hal. 24.

Djajasewaka, H. 1985. Pakan Ikan. Yasaguna. Jakarta.

Effendi, H. 2003. Telaah Kualitas Air: Bagi Pengelolaan Sumbder Daya dan Lingkungan Perairan. Kanisius. Yogyakarta. hal. $50-157$.

Effendie, M. I. 2002. Biologi Perikanan. Yayasan Pustaka Nusatama. Bogor. Hal. 128-132.

Effendie, M.I. 1997. Biologi Perikanan Yayasan Pustaka Nusatama. Yogyakarta. Hal. 92-105

Fujaya, Y. 2004. Fisiologi Ikan : Dasar Pengembangan Teknik Perikanan. Rineka Cipta. Jakarta. hal. 131.

Gusrina, 2008. Budidaya Ikan. Edisi Pertama. Departemen Pendidikan Nasional. Jakarta. www.ftp.lipi.go.id 22 Oktober 2010. 212 hal.

Handajani, H. 2008. Pengujian Tepung Azolla Terfermentasi Sebagai Penyusun Pakan Ikan Terhadap Pertumbuhan dan Daya Cerna Ikan Nila Gift. Fakultas Peternakan Perikanan. Universitas Muhammadiyah Malang. Malang.

Hapsari, S. W. N. 2010. Pengaruh Ekstrak Jahe (Zingiber officinale) Terhadap Penghambatan Mikroba Perusak Pada Ikan Nila (Oreochromis niloticus). Skripsi. Fakultas Ilmu Kesehatan. 
Universitas Muhammadiyah Surakarta. Surakarta.

Hariyadi, B. A., Haryono dan U. Susilo. 2005. Evaluasi Efisiensi Pakan dan Efisiensi Protein pada Ikan Karper Rumput (Ctenopharyngodon idella Val.) yang Diberi Pakan Dengan Kadar Karbohidrat dan Energi yang Berbeda. Fakultas Biologi. Universitas Soedirman. Hal. 1-6.

Irianto, A. 2005. Patologi Ikan Teleostei. Gajah Mada University Press. Yogyakarta. 256 hal.

Khairuman dan Amri, K. 2003. Membuat Pakan Ikan Konsumsi. PT AgroMedia Pustaka. Depok, 83 hal.

Kusriningrum, R. S. 2008. Perancangan Percobaan. Universitas Airlangga. Surabaya. hal. 43-63.

Lovell, T. 1988. Nutrition and Feeding of Fish. Auburn University. New York. ISBN 0-442-25927-1. hal. 19.

Mudjiman, A. 2002. Makanan Ikan. Penebar Swadaya. Jakarta. hal. 100-178.

Mulyana, T. Z. 2004. Efisiensi Pemberian beberapa Pakan untuk Ikan Sidat (Anguilla sp.) yang Dipelihara dalam Sistem Resirkulasi. Skripsi. Departemen Budidaya Perairan. Fakultas Perikanan dan Ilmu Kelautan. Institut Pertanian Bogor. Bogor. 50 hal.

National Research Council (NRC). 1997. NutrientRequirement of Warmwater Fishes. Sub Committee On Warmwater Fish Nutrition. Committee on Animal Nutrition. Board on Agriculture and Renewable Resources. National Academy of Science. Washington, D. C. hal. 120 .

Nofyan, E. 2005. Pengaruh Pemberian Pakan dari Sumber Nabati dan Hewani Terhadap Berbagai Aspek Fisiologi Ikan Gurami (Osphronemus gouramy). Jurnal Ikhtiologi Indonesia Volume 5 nomor 1. Universitas Sriwijaya. Ogan Ilir. 1-3 hal.
Paramita, W.T. 2009. Handout Nutrisi Ikan. Fakultas Kedokteran hewan. Universitas Airlangga. Surabaya.

Philips, J. 1972. Calory and Energy Recruitment in Fish Nutrition. Academic Press Inc. New York. 713p.

Pramita D.S, 2008. Pengaruh Teknik Pemanasan Terhadap Kadar Asam Fitat dan Aktivitas Antioksidan Koro Benguk (Mucuna pruriens), Koro Glinding (Phaseolus lunatus) dan Koro Pedang (Canavalia ensiformis). Skripsi. Surakarta : Jurusan Teknologi Hasil Pertanian FP UNS.

Sikong, M. 1982. Beberapa Faktor Lingkungan yang Mempengaruhi Biomassa Udang (Penaeus Monodon). Desertasi Doktor. Fakultas pasca Sarjana. Institut Pertanian Bogor.

Susilo, U., A. Haryono dan B. Hariyadi. 2005. Evaluasi Efisiensi Pakan dan Efisiensi Protein pada Ikan Karper Rumput (Ctenopharyngodon idella Val.) yang Diberi Pakan dengan Kadar Karbohidrat dan Energi yang Berbeda. Ichthyos, Vol. 4, No. 2: 87-92.

Suyanto, S.R. 2009. Nila. Cetakan ke-XV. Penebar Swadaya. Jakarta. Hal 1-6.

Watanabe T. and C.Y Cho,.1988. Laboratory work chemical evaluation of dietary nutrition p. 79-92. In. Watanabe T, editor. Fish nutrition and mariculture JICA textbook the, General Aquaculture Course. Tokyo : Kanagawa International Fisheries Training Center. 